УДК 343.322

DOI https://doi.org/10.32849/2663-5313/2020.4.52

\title{
Алла Левчук-Микитюк,
}

аспірантка кафедри кримінального права і прочесу

юридичного факультету

Східноєвропейського нащіонального університету імені Лесі Українки

\section{ВИЗНАЧЕННЯ СУБ'СКТА СКЛАДУ ЗЛОЧИНУ «ДЕРЖАВНА ЗРАДА»}

Стаття присвячена дослідженню особливостей визначення суб'єкта кримінального правопору шення, передбаченого ст. 111 КК Украйни. У ході аналізу наукових пращь, що стосуються питання визначення суб'єкта злочину «державна зрада», встановлено, що в теорії вітчизняного кримінального права ие питання досліджувалось опосередковано, що й зумовлює об'єктивну потребу його детального вивчення. У статті розкрито зміст ознак суб'єкта злочину, передбаченого ст. 111 КК України, шляхом аналізу його обов'язкових ознак - фізичної природи, осудності та віку, з якого може наставати кримінальна відповідальність, а також спещіальної ознаки - громадянства України. Зокрема, аргументовано, що зазначений злочин не може бути вчинений уповноваженою особою від імені чи в інтересах юридичної особи. Проаналізовано аргументи на підтримання зниження віку особи, з якого вона може нести кримінальну відповідальність за державну зраду. При иьому досліджено ситуачію, в якій опинилися неповнолітні громадяни України, котрі натепер проживають на території квазідержавних утворень - ДНР, ЛНР та анексованої частини України - АР Крим, за якої на їхні психофізіологічні та сочіальні особливості розвитку здійснюється наскрізний антиукраїнський вплив, що не виключає можливість свідомого вчинення дій на шкоду державному суверенітету України особами, які не досягли 16-річного віку. Досліджуючи особливості спечіальної ознаки злочину «державна зрада», встановлено, що норми чинного законодавства Украйни, які регулюють питання втрати громадянства України, є дискусійними. Зокрема, встановлено, що добровільне набуття громадянином України громадянства іншої держави, якшо на момент такого набуття він досяг повноліття, $\epsilon$ однією з підстав втрати громадянства України, однак механізм реалізаиії ивого припису Законом не передбачений, що породжує низку суперечностей. У ході дослідження законопроєкту № 2590 «Про внесення змін до деяких законів України щодо питань громадянства», що в грудні 2019 року поданий до ВР України, встановлено, що окремі його положення покликані вирішити прогалини законодавчоі бази з питань громадянства України, які нині становлять реальну загрозу державній безпеці.

Ключові слова: суб'єкт злочину, фізична особа, осудна особа, вік кримінальної відповідальності, зниження граничної межі, спеціальний суб'єкт злочину, громадянство України.

Постановка проблеми. Велике значення для вирішення проблеми юридичного аналізу будь-якого складу злочину має характеристика суб'єкта протиправного діяння. Суб'єкт злочину є одним з обов'язкових елементів складу кримінально караного діяння. 3 цього приводу О.М. Омельчук зазначає, що «правильне встановлення ознак суб'єкта злочину важливе з багатьох причин. Це нерідко дає можливість визначити ознаки об'єктивної і суб'єктивної сторони, а також об'єкта злочину. Справа ще й в тому, що посягання на деякі суспільні відносини можуть бути вчинені лише обмеженим колом осіб» $[1$, с. 110].

За умов російської агресії на Сході України протягом останніх шести років особливої актуальності набула проблема притягнення до кримінальної відповідальності осіб, котрі вчинили державну зраду. Зважаючи на значне збільшення кількості таких злочинів, доцільним є дослідження особливос- тей суб'єкта злочину, передбаченого ст. 111 КК України.

Аналіз останніх досліджень і публікацій. Теорія кримінального права не містить детального вивчення питання суб'єкта складу злочину «державна зрада». Окремі аспекти такої проблеми були висвітлені в працях О.Ф. Бантишева, Н.С. Кончук, М.І. Хавронюка, О.А. Чувакова, О.В. Шамари. Однак, за винятком дисертації Н.С. Кончук, це питання науковцями розглядалося опосередковано під час вивчення питання кримінально-правової характеристики злочинів проти основ національної безпеки загалом.

| Формулювання мети статті. Виходячи 3 наведених міркувань, основною метою цієї статті є визначення ознак суб'єкта державної зради.

Виклад основного матеріалу. У Розділі IV Загальної частини КК України 2001 року 
«Особа, яка підлягає кримінальній відповідальності (Суб'єкт злочину)» сформульовано загальну модель суб'єкта складу злочину, яка закріплює поняття, обов'язкові ознаки та інші особливості суб'єкта злочину. Так, відповідно до ч. 1 ст. 18 КК України суб'єктом злочину $€$ фізична осудна особа, яка вчинила злочин у віці, з якого може наставати кримінальна відповідальність [2].

Наведене визначення містить такі обов'язкові ознаки, що характеризують суб'єкта злочину, як: фізична особа, яка вчинила кримінально каране діяння; осудна особа; особа, яка досягла віку, з якого відповідно до норм КК України може наставати кримінальна відповідальність. Проте притягатися до кримінальної відповідальності за окремі кримінально карані діяння можуть лише особи, котрі відповідно до ч. 2 ст. 18 КК України віднесені до категорії спеціальних суб'єктів злочину.

Розкриття змісту ознак суб'єкта злочину, передбаченого ст. 111 КК України, варто розпочати з його першої обов'язкової ознаки - належності до категорії фізичних осіб. Ця ознака закріплює можливість притягнення до кримінальної відповідальності за вчинення будь-якого кримінально караного діяння виключно фізичних осіб. Зауважу, що питання притягнення до кримінальної відповідальності юридичних осіб нині залишається дискусійним у теорії вітчизняного кримінального права.

3 цього приводу Н.С. Кончук зазначає, що позиція законодавця в цьому разі $€$ виправданою та відповідає принципам індивідуальності кваліфікації (індивідуальність кваліфікації стосується оцінки кожного злочину окремо та означає, що кримінально-правова оцінка діяння кожної особи стосується лише її самої) та особистої відповідальності (особа, яка вчинила злочинне діяння, підлягає особистій кримінальній відповідальності. Відповідно, неприпустимо покладати на неї кримінальну відповідальність за злочин, який було вчинено іншою особою, а також неможливо притягати до кримінальної відповідальності юридичну особу) [3, с. 103]. Крім того, таке положення фактично закріплене у ст. ст. 6-10 КК України, в яких зазначено, що нести кримінальну відповідальність можуть громадяни України, іноземці та особи без громадянства.

Досліджуючи суб'єкт злочину «державна зрада», необхідно проаналізувати розділ XIV-1 «Заходи кримінально-правового характеру щодо юридичних осіб», яким було доповнено Загальну частину КК України відповідно до Закону України № 314-VII від 23 травня 2013 року. Так, норми зазначеного розділу КК України визначають види кримінально-правових заходів щодо юридичних осіб, підстави та правила їх застосування, порядок звільнення від них та види юридичних осіб, до яких вони можуть бути застосовані. У переліку ж злочинів, передбачених розділом XIV-1 Загальної частини КК України, немає вказівки на злочин, що встановлює відповідальність за вчинення державної зради, а тому він не може бути вчинений уповноваженою особою від імені чи в інтересах юридичної особи.

Ще однією обов'язковою ознакою суб'єкта державної зради є його осудність. Відповідно до ст. 19 КК України осудною визнається особа, яка під час скоєння злочину могла усвідомлювати свої дії (бездіяльність) і керувати ними. Питання осудності особи виникає лише тоді, коли з'являються сумніви з приводу здатності особи на момент вчинення нею суспільно небезпечного діяння усвідомлювати характер та значення своїх злочинних дій і керувати ними та вирішується шляхом проведення судово-психіатричної експертизи. Разом із тим відповідно до ч. 1 ст. 20 КК України кримінальній відповідальності також підлягає особа, визнана судом обмежено осудною, тобто така, яка під час скоєння злочину через наявний у неї психічний розлад не була здатна повною мірою усвідомлювати свої дії (бездіяльність) та (або) керувати ними [2]. Однак суд, враховуючи особливу природу психічного розладу, під час призначення покарання може застосувати стосовно такої особи примусові заходи медичного характеру.

Обов'язковою ознакою суб'єкта злочину «державна зрада» $є$ також вік, з якого може наставати кримінальна відповідальність. Відповідно до ч. 1 ст. 22 КК України притягатися до кримінальної відповідальності можуть особи, яким до вчинення ними кримінально караного діяння виповнилось 16 років. Однак уже у ч. 2 ст. 22 КК України наведений вичерпний перелік злочинів, за скоєння яких кримінальна відповідальність настає за зниженим віком - 14 років. У цьому переліку відсутнє згадування ст. 111 КК України, а тому державна зрада матиме місце лише, якщо відповідне суспільно небезпечне діяння вчинила особа віком 16 років.

Проте все частіше в кримінально-правовій літературі трапляються думки з приводу того, що зниження віку, з якого може наставати кримінальна відповідальність за вчинення того чи іншого злочину, є заходом, що сприяв би вирішенню проблеми дитячої та підліткової злочинності, зважаючи на їі підвищений рівень та відсутність ефективної протидії. Для встановлення зниженого віку 
кримінальної відповідальності за вчинення кримінально караного діяння необхідно враховувати низку чинників: високий ступінь суспільної небезпеки зазначених злочинів та специфічність розвитку підлітків, їх здатність розуміти суспільне значення відповідних діянь та у разі їх вчинення - обов'язок нести покарання. 3 цього приводу О.А. Плашовецький слушно зазначає, що досягнення встановленого віку, з якого може наставати кримінальна відповідальність, передбачає також наявність в особи здатності правильно сприймати покарання, бо тільки в такому разі досягається його мета [4, с. 54]. Крім того, вирішуючи питання про можливість зниження віку, з якого настає кримінальна відповідальність за державну зраду, необхідно усвідомлювати, чи здатна особа віком до 16 років ставити перед собою ціль діяти умисно на шкоду інтересам держави та іï безпеки, оскільки процес визначення таких цілей потребує потужної інтелектуальної діяльності.

Досліджуючи питання можливості та необхідності зниження віку кримінальної відповідальності суб'єкта державної зради, варто вивчити й судову практику та статистичну інформацію притягнення до відповідальності осіб за скоєння такого злочину. Відповідно до статистичної інформації Офісу Генерального прокурора України про осіб, які вчинили кримінальні правопорушення, встановлено, що в період 2016-2019 рр. до кримінальної відповідальності за скоєння злочину, передбаченого ст. 111 КК України, були притягнені особи віком від 18 років [5]. I все ж сьогодні немає можливості отримати об'єктивні статистичні дані про кількість осіб, котрі беруть участь у збройному конфлікті проти України на боці так званих ДНР та ЛНР та які не досягли віку, з якого може наставати кримінальна відповідальність за державну зраду.

Складність проведення дослідження питання зниження віку, з якого може наставати кримінальна відповідальність, насамперед полягає у тому, що законодавець, встановлюючи вікові межі для притягнення особи до кримінальної відповідальності, має враховувати не лише природні та біологічні властивості людини, а й соціально-психологічні аспекти. Н.А. Орловська, В.М. Бурдін та Я.Б. Заєць з цього приводу вважають, що варто встановити мінімальний вік, з якого може наставати кримінальна відповідальність на рівні 11 років. При цьому, як зазначає остання, такий вік настання кримінальної відповідальності варто встановлювати за умов, якщо неповнолітні у зазначеному віці можуть усвідомлювати суспільну небез- пеку скоєних злочинів, що підтверджується висновками психологічних та медичних досліджень [6, с. 92]. Авторка, грунтуючись на факторах, що впливають на психологічний розвиток кожної людини, а саме: на умовах та оточенні, в якому виховується дитина, а також з урахуванням вікових особливостей розвитку сучасних малолітніх та неповнолітніх осіб та досвіду зарубіжних країн вважає найбільш оптимальним віком, до якого варто зменшити вік кримінальної відповідальності в чинному КК, - 14 років, а за окремі злочини - $11[6$, с. 92$]$.

I все ж домінуючою пропозицією у доктрині кримінального права є зниження мінімальних меж кримінальної відповідальності до 12 років [7, с. 83]. При цьому більшість учених обгрунтовують таку свою позицію достатнім рівнем інтелектуального потенціалу особи віком 12 років, що дає змогу сприймати, запам'ятовувати та аналізувати інформацію, необхідну для вчинення певних дій, а також усвідомлювати їх наслідки.

Що стосується зарубіжного досвіду в питанні віку, з якого може наставати кримінальна відповідальність, то в деяких країнах кримінальна відповідальність настає 37 років (Швейцарія, Ірландія), з 10 років (Австралія, Англія), з 12 років (Канада, Кіпр, Сан-Марино) і 13 років (Франція, штати Нью-Йорк, Джорджія, Іллінойс у США). На Алясці, в Алабамі, Флориді та деяких інших штатах взагалі не визначено мінімальну вікову межу - відповідальність залежить від розсуду суду в кожному конкретному випадку [8].

Досліджуючи питання необхідності зниження віку особи, з якого вона може нести кримінальну відповідальність за державну зраду, варто проаналізувати ситуацію, в якій опинилися громадяни України, котрі натепер проживають на території квазідержавних утворень - ДНР, ЛНР та анексованої частини України - АР Крим. 3 початком бойових дій РФ на зазначених територіях почала створюватися нова колективна свідомість регіону через формування концепції Новоросії, осереддям якого начебто є Донбас. Як слушно зазначає В.С. Лозовий, оскільки школа значною мірою впливає на свідомість молодого покоління, особливий акцент у процесі формування антиукраїнської ідеології у квазіреспубліках поставлено на «реформі освіти». Автор відзначає, що в МОН ДНР вважають, що результатами роботи української системи освіти за попередні 25 років стали «популяризація нацизму, неприйняття об'єктивної історії, заперечення традиційних цінностей», а тому важливими кроками реформування системи освіти ДНР мають стати 
позбавлення «елементів української націоналістичної пропаганди і маніпулювання істоpiєю» [9, c. 224].

Однією ж з основних цілей реформування системи освіти у ДНР вбачають у «вихованні справжнього патріота Донецької Народної Республіки», для чого й створено концепцію патріотичного виховання дітей та учнівської молоді, згідно 3 якою військово-патріотичне виховання оголошується одним 3 пріоритетів [10], а увагу учнів 11 класів акцентують на потребі служби в армії та захисті «батьківщини». Крім того, в ДНР, ЛНР та АР Крим відкриваються дитячі військово-спортивні табори. Очевидно, що таке виховання надзвичайно мілітаризоване, адже на ранках у дитячих садках та школах діти у камуфляжних костюмах мають при собі іграшкову зброю, а у букварі надруковані вірші на честь бойовиків.

Отже, слід констатувати наявність об'єктивних обставин, за яких на психофізіологічні та соціальні особливості розвитку неповнолітніх громадян України, що перебувають на тимчасово окупованих РФ територіях, здійснюється наскрізний антиукраїнський вплив через упровадження нових проросійських методів навчання, а також через телебачення, книги, кіно та радіо, відбувається інтенсивний розумовий розвиток таких осіб, а період їх переходу від дитинства до юності та становлення особистості взагалі суттєво скорочується. Тому, на наш погляд, не виключається можливість свідомого вчинення дій на шкоду державному суверенітету України особами, які не досягли 16-річного віку.

До того ж про зниження віку кримінальної відповідальності до 12 років позитивно відгукуються і вчені суміжних із вказаною проблематикою галузей наук: вчені-психологи вказують, що з 12 років у неповнолітніх встановлюється здібність до свідомого регулювання поведінки у кримінально значущих ситуаціях [11, с. 171]; віком близько 12 років у особи відбувається логічне упорядкування думок, спостерігається різке збільшення об'єму її мислення у просторі та у часі, значною мірою розширюється коло джерел інформації, абстрактне мислення набуває достатнього рівня [12, с. 88].

При цьому, як зазначає М.О. Карпенко, необхідно пам'ятати вимоги Мінімальних стандартних правил ООН, що стосуються відправлення правосуддя щодо неповнолітніх: у правових системах, які визначають поняття віку кримінальної відповідальності для неповнолітніх, нижня його межа не має встановлюватися на дуже низькому віковому рівні з урахуванням емоційної, духовної та інтелектуальної зрілості підлітка $[13$, c. 389$]$.
Таким чином, встановлений законодавцем вік 16 років, з якого може наставати кримінальна відповідальність для суб'єкта складу злочину «державна зрада», не є адаптованим до умов, в яких опинилося українське суспільство нині. Це питання потребує детального вивчення та аналізу, зокрема й світових тенденцій щодо гуманізації кримінальних покарань, задля того, щоб зменшення нижньої межі віку, з якого може наставати кримінальна відповідальність, було цілком обгрунтованим. Разом із тим, вирішуючи питання доцільності зниження віку кримінальної відповідальності за державну зраду, варто керуватися даними медичних та психологічних досліджень, а також ураховувати індивідуальні особливості розвитку неповнолітніх, віднесених до різних верств населення й насамперед тих, які проживають на окупованій території України та піддаються щоденному впливу агресора.

3 диспозиції ст. 111 КК України, якою передбачено відповідальність за державну зраду, очевидно, що такий злочин може бути вчинений лише спеціальним суб'єктом, на що вказує його додаткова ознака - громадянство України. Утім, як слушно зазначають О.Ф. Бантишев та О.В. Шамара, у подібних випадках більш правильно говорити не про спеціального суб'єкта, а про спеціального виконавця, оскільки співучасниками в такого роду злочинах (організаторами, підбурювачами, пособниками) можуть бути й особи, які не $є$ такими [14, ст. 150].

Своєю чергою О.А. Чуваков зазначає, що громадянство України як ознака спеціального суб'єкта складу злочину, передбаченого ст. 111 КК України, акцентує увагу на особливості процедури притягнення до кримінальної відповідальності 3 урахуванням положень кримінального законодавства, що характеризує такий стан [15, с. 325].

Правовий зміст громадянства України, а також підстави й порядок його набуття та припинення регулюється Законом України «Про громадянство» від 18 січня 2001 року. Відповідно до ст. 1 зазначеного Закону громадянином України визнається особа, яка набула громадянство України в порядку, передбаченому законами України та міжнародними договорами України [16]. Своєю чергою стаття 3 цього Закону містить перелік осіб, які мають належність до громадянства України. Зокрема, громадянами України є: всі громадяни колишнього СРСР, які на момент проголошення незалежності України (24 серпня 1991 року) постійно проживали на території України; особи, незалежно від раси, кольору шкіри, політичних, релігійних та інших переконань, 
статі, етнічного та соціального походження, майнового стану, місця проживання, мовних чи інших ознак, які на момент набрання чинності Законом України «Про громадянство України» (13 листопада 1991 року) проживали в Україні і не були громадянами інших держав; особи, які прибули в Україну на постійне проживання після 13 листопада 1991 року і яким у паспорті громадянина колишнього СРСР зразка 1974 року органами внутрішніх справ України внесено напис «громадянин України», та діти таких осіб, які прибули разом із батьками в Україну і на момент прибуття в Україну не досягли повноліття, якщо зазначені особи подали заяви про оформлення належності до громадянства України; особи, які набули громадянство України відповідно до законів України та міжнародних договорів України [16].

Водночас система національного законодавства про громадянство грунтується насамперед на принципі єдиного громадянства, що закріплений у статті 2 вищевказаного Закону. Такий принцип передбачає, що громадянин України не може одночасно перебувати в громадянстві іншої держави, а також виключається можливість існування громадянства адміністративно-територіальних одиниць України. Разом із тим відповідно до ч. 1 ст. 19 Закону «Про громадянство України» добровільне набуття громадянином України громадянства іншої держави, якщо на момент такого набуття він досяг повноліття, є однією з підстав втрати громадянства України, однак механізм реалізації цього припису Законом не передбачений. У цьому контексті M.I. Хавронюк зазначає таке: якщо під час провадження у справі буде встановлено, що особа, яка обвинувачується у державній зраді, має, крім українського, ще й громадянство іншої держави, слід виходити із того, що набуття нею іноземного громадянства виключає її з числа громадян України. Тому вчинені нею шпигунські дії слід кваліфікувати за ст. 114, а діяння, вчинені нею в інших формах із числа передбачених ст. 111, - за відповідними іншими статтями Особливої частини КК, якщо фактично вчинене містить склад іншого злочину [17, с. 821].

Однак варто зазначити, що особа вважається громадянином України доти, доки вона у встановленому законом порядку не буде його (громадянства) позбавлена. Процедура припинення громадянства України закріплена в «Положенні про Комісію при Президентові України з питань громадянства», що затверджена Указом Президента України від 27 березня 2001 року № 215 (в редакції Указу Президента України від 27 червня 2006 року № 588/2006).
Так, відповідно до Порядку провадження за заявами і поданнями з питань громадянства України та виконання прийнятих рішень вищевказаного Положення для припинення громадянства України внаслідок його втрати територіальні органи Державної міграційної служби України, дипломатичні представництва чи консульські установи України готують та подають: подання про втрату громадянства України; документ, що підтверджує перебування особи у громадянстві України; у визначених Законом випадках документ, який підтверджує, що громадянин України внаслідок втрати громадянства України не стане особою без громадянства та один із таких документів: документ, що підтверджуе добровільне набуття громадянином України громадянства іншої держави, разом із документом, який підтверджує, що на момент такого набуття громадянин України досяг повноліття; документ, який підтверджує, що особа набула громадянство України на підставі статті 9 Закону внаслідок обману, свідомого подання неправдивих відомостей або фальшивих документів; документ, який підтверджує, що громадянин України добровільно вступив на військову службу іншої держави, яка відповідно до законодавства цієї держави не є загальним військовим обов'язком чи альтернативною (невійськовою) службою [18]. Дипломатичне представництво чи консульська установа України, до якої подано документи щодо виходу особи з громадянства України, здійснюе перевірку оформлення поданих документів на відповідність вимогам законодавства України та підтвердження ними виконання умов виходу з громадянства України. У разі належного оформлення зазначених документів дипломатичне представництво чи консульська установа України готують висновок про можливість задоволення клопотання заявника та надсилають його разом iз поданими документами до Міністерства закордонних справ України (ст. 106), котре, своєю чергою, скеровує зазначені документи до Міністерства внутрішніх справ та Служби безпеки України (ст. 107). Далі відповідно до п. 4 ст. 107 Положення, відповідні документи передають до Комісії при Президентові України з питань громадянства. Однак процедура втрати громадянства України на підставі набуття громадянства іншої держави на цьому етапі не завершується. Так, рішення про припинення громадянства ухвалює виключно Президент України, про що видає відповідний Указ (ст. 113). При цьому датою припинення громадянства вважається дата видання відповідного Указу. Таким чином, громадянин України, щодо якого 
проводиться процедура виходу 3 громадянства України, до видання відповідного указу Президента України про припинення громадянства України користується всім обсягом прав, що притаманні громадянам України. Крім того, передбачається, що такий громадянин перебуває під суверенітетом української держави, яка має його захищати. За таких умов цілком логічною видається вимога держави до такого громадянина - виконувати певні обов'язки, в тому числі й обов'язки не вчиняти дій, що охоплюються об'єктивною стороною складу злочину «державна зрада». А у разі вчинення вказаним громадянином суспільно небезпечного діяння, яке містить ознаки державної зради, така особа має нести кримінальну відповідальність за ст. 111 КК України.

Беззаперечним є і факт переходу на бік ворога великої кількості осіб, які, будучи представниками влади під час анексії Криму та окупації РФ частини територій Донецької та Луганської областей, здійснили та продовжують здійснювати підривну діяльність проти України. Отже, якщо питання віднесення таких осіб до числа громадян України на момент анексії АР Крим та вчинення перших окупаційних заходів з боку РФ не викликає сумнівів, то в питанні кваліфікації їхньої подальшої протиправної діяльності стосовно української держави (після набуття ними громадянства РФ) залишається низка невизначених моментів.

Разом із тим п. 6 ст. 1 ЗУ «Про військовий обов'язок і військову службу» передбачено, що у визначених законом випадках іноземці та особи без громадянства, які на законних підставах перебувають на території України, можуть у добровільному порядку (за контрактом) проходити військову службу у Збройних силах України [19]. За таких обставин іноземці та особи без громадянства потенційно мають розглядатися як суб'єкт злочину «державна зрада», адже будучи військовослужбовцями ЗС України здатні щонайменше здійснити перехід на бік ворога. Однак притягнути таких осіб до кримінальної відповідальності неможливо, позаяк вони не є суб'єктом злочину, передбаченого ст. 111 КК України.

Варто зазначити, що в грудні 2014 року до ВР України було подано проєкт Закону № 1297 «Про внесення змін до деяких законодавчих актів України щодо припинення громадянства України осіб, котрі вчинили злочини проти основ національної безпеки України». Відповідно до цього законопроєкту абзац другий частини першої ст. 111 КК України передбачалося доповнити словами «3 припиненням громадянства України», а розділ III Закону України «Про громадянство України» пропонувалося доповнити статтею 19-1, відповідно до якої підставою припинення громадянства України було б вчинення злочину проти основ національної безпеки України [20]. Однак цей проєкт Закону в серпні 2019 року був відкликаний.

Натомість у грудні 2019 року до ВР України подано проєкт Закону № 2590 «Про внесення змін до деяких законів України щодо питань громадянства», який наразі очікуе розгляду ВР України у другому читанні. У цьому законопроєкті серед низки новел пропонується: вирішити питання використання паспорта громадянина колишнього СРСР зразка 1974 року як документа, що може бути підставою для набуття громадянства України; розширити коло осіб, які набувають громадянство України за територіальним походженням шляхом віднесення до кола осіб, родинний зв'язок з якими надає право особі на набуття громадянства України за територіальним походженням; переглянути підстави втрати громадянства Украіни, а саме виключення з підстав для втрати громадянства України такої підстави, як добровільне набуття повнолітнім громадянином України громадянства іншої держави, та низка інших.

Так, перші два з перерахованих положень законопроєкту зроблять можливим вирішити питання щодо віднесення до числа громадян України осіб, які фактично є етнічними українцями та здебільшого постійно проживають в Україні. Однак нині у разі вчинення такими особами державної зради у формі переходу на бік ворога чи надання іноземній державі, іноземній організації або їхнім представникам допомоги в проведенні підривної діяльності проти України притягнути їх до кримінальної відповідальності неможливо, оскільки вони не є суб'єктом такого злочину. Що ж стосується виключення 3 підстав для втрати громадянства України добровільного набуття повнолітнім громадянином України громадянства іншої держави, то таке положення усуває наявну в законодавстві колізію, коли громадянин України в такому разі не проходить визначеної Законом процедури втрати громадянства, а тому вважається громадянином України до дня підписання Президентом України відповідного Указу та несе кримінальну відповідальність за скоєння злочину проти держави як громадянин України. I хоча відповідно до Висновку Головного науково-експертного управління від 11.01.2020 на цей законопроєкт зазначено, що це положення варто розцінювати як ідею більш лояльного ставлення до подвійного (множинного) громадянства 
в Україні, такі зміни є необхідними насамперед в інтересах національної безпеки України. Таким чином, зазначені вище положення законопроєкту № 2590 від 13.12.2019 покликані вирішити прогалини законодавчої бази з питань громадянства України, що нині становлять реальну загрозу державній безпеці.

\section{Висновки}

Проведене дослідження свідчить про те, що суб'єктом складу злочину, передбаченого ст. 111 КК України, є фізична осудна особа, яка досягла шістнадцятирічного віку та є громадянином України.

Досліджуючи питання віку, 3 якого може наставати кримінальна відповідальність за державну зраду, ми дійшли висновку, що вже нині воно потребує ретельного вивчення та аналізу з метою внесення змін до КК України в частині зменшення його нижньої межі, що буде адаптована до умов сучасного українського суспільства. Такі кардинальні заходи зумовлені насамперед становищем неповнолітніх громадян України, котрі прямо чи опосередковано використовуються бойовиками квазідержавних утворень - ДНР та ЛНР у ході ведення бойових дій та залучаються до участі у воєнізованих молодіжних групах, де навчаються використовувати та застосовувати зброю проти українських військових та мирних громадян. Разом із тим зниження віку настання кримінальної відповідальності за державну зраду є обгрунтованим і досвідом розвинутих зарубіжних країн, в яких мінімальний вік, з якого може наставати кримінальна відповідальність, варіюється в межах 7-13 років.

Крім того, в дослідженні питання додаткової ознаки суб'єкта державної зради - громадянства України встановлено, що чинне законодавство з питань громадянства містить дискусійні норми в частині втрати громадянства України. Адже, незважаючи на закріплену процедуру набуття та втрати громадянства України, що визначена відповідним Положенням про Комісію при Президентові України з питань громадянства, питання віднесення осіб, котрі будучи громадянами України набули громадянства іншої держави, до суб'єкта складу злочину, передбаченого ст. 111 КК України, породжує низку суперечностей. Разом із тим іноземці та особи без громадянства, котрі у відповідності до Закону проходять військову службу в ЗС України, а також особи з числа етнічних українців, котрі досі користуються паспортом громадянина колишнього СРСР зразка 1974 року та постійно проживають на території України, взагалі не належать до суб'єкта злочину, передбаченого ст. 111 КК України, що унеможливлює притягнення їх до кримінальної відповідальності за його вчинення. Таким чином, законодавчі норми, що регулюють питання громадянства України, натепер залишаються дискусійними та потребують докладного вивчення. Усунення відповідних суперечностей у процедурі встановлення ознак суб'єкта складу злочину «державна зрада» призведе до правильної кримінально-правової оцінки подібних злочинних проявів. Отримані висновки можуть бути використані під час подальших наукових досліджень особливостей кримінальної відповідальності за державну зраду у сучасній Україні.

\section{Список використаних джерел:}

1. Омельчук О.М. Кримінально-правова характеристика суб'єкта злочину, передбаченого ст. 304 Кримінального кодексу України. Вісник Хмельнииького інституту регіонального управління та права. 2003. № 2. С. 110-115.

2. Кримінальний кодекс України. Вiдомості Верховної Ради Украӥни, 2001. № 25-26, ст.131. URL: https://zakon.rada.gov.ua/laws/ show/2341-14 (дата звернення: 05.03.2020).

3. Кончук Н.С. Кримінальна відповідальність за державну зраду : дис. ... канд. юрид. наук. Львів, 2019. 218 с.

4. Плашовецький О.А. Кримінальна-правова дефініція віку : дис. ... канд. юрид. наук. Львів, 2017. $200 \mathrm{c}$.

5. Статистична інформація про стан злочинності та результати роботи прокурорсько-слідчої діяльності. Офіційний веб-сайт (Офіс Генерального Прокурора України) URL: https://old.gp.gov.ua/ua/ statinfo.html (дата звернення: 05.03.2020).

6. Заєць Я. До проблеми встановлення кримінальної відповідальності за злочини, скоєні неповнолітніми особами. Наукові записки Інсти туту законодавства Верховної Ради Украйни. 2014. № 5. URL: http://instzak.rada.gov.ua/instzak/ control/uk/publish/article?art_id (дата звернення: 05.03.2020).

7. Мирошниченко Н.М. Вікова осудність неповнолітніх у кримінально-правовій доктрині України : дис. ... канд. юрид. наук : 12.00.08. Одеса, 2013. C. 203.

8. Сергатий М., Лавренко М. Визначення віку кримінальної відповідальності у кримінальному праві зарубіжних країн. URL: http://vk.com/ doc21189868 168773708 ?hash=fb345f17f624885 $052 \& \mathrm{dl}=0809 \overline{6} \mathrm{~d} 05 \mathrm{~d} 29 \mathrm{e} 01524 \mathrm{~d}$ （дата звернення: 05.03.2020).

9. Лозовий В.С. Гуманітарна політика квазідержавних утворень «ДНР» та «ЛНР». Освіта, наука $i$ культура на Поділлі. 2017. Т. 24. С. 223-231.

10. Приказ № 322 от 17.07.2015 «Об утверждении Концепции патриотического воспитания детей и учащейся молодёжи». URL: http: //old. mondnr.ru/?p=28091 (дата звернення: 05.03.2020). 
11. Кудрявцев И.Б. Судебная психолого-психиатрическая експертиза. Москва : Юрид. лит. 1988. C. 224

12. Блонский П.П. Избранные педагогические и психологические сочинения. Москва : Педагогика. 1979. Т. 2. С. 400.

13. Карпенко М.О. Деякі питання вирішення справ про суспільно небезпечні діяння вчинені особою, яка не досягла віку, з якого можлива кримінальна відповідальність II Університетські наукові записки. 2007. № 4. C. 388-392.

14. Бантишев О.Ф., Шамара О.В. Кримінальна відповідальність за злочини проти основ національної безпеки України (проблеми кваліфікації) : монографія. Луганськ : ТОВ «Віртуальна реальність», 2014. 240 с.

15. Чуваков О.А. Злочини проти основ національної безпеки України: проблеми кримінально-правової теорії і практики : монографія. Одеса. 2017. 362 с.

16. Про громадянство України : Закон України від 18 січня 2001 р. № 2235-III. URL: http://zakon4.rada.gov.ua/laws/show/2235-14 (дата звернення: 05.03.2020)
17. Дудоров О.О., Хавронюк М.І. Кримінальне право : навчальний посібник / За заг. ред. М.I. Хавронюка. Київ : Ваіте, 2014. С. 944.

18. Положення про Комісію при Президентові України з питань громадянства від 27 березня 2001 р. № 215 (в редакції Указу Президента України від 27 червня 2006 р. № 588/2006). URL: https://zakon.rada.gov.ua/laws/show/588/ 2006 (дата звернення: 05.03.2020).

19. Про військовий обов'язок і військову службу : Закон України від 25 березня 1992 р. № 2232-XII. URL: https://zakon.rada.gov.ua/laws/ show/2232-12 (дата звернення: 05.03.2020).

20. Про внесення змін до деяких законодавчих актів України щодо припинення громадянства України осіб, котрі вчинили злочини проти основ національної безпеки України:проєкт Закону від 08 грудня 2014 p. № 1297. URL: http://w1.c1.rada.gov.ua/ pls/zweb2/webproc4_1?pf3511=52759 (дата звернення: 05.03.2020)

21. Про внесення змін до деяких законів України щодо питань громадянства : проєкт Закону від 13 грудня 2019 р. № 2590. URL: http:// w1.c1.rada.gov.ua/pls/zweb2/webproc4 1?pf3511= 67632 (дата звернення: 05.03.2020).

The article is devoted to the study of the peculiarities of the definition of the subject of the criminal offense under Art. 111 of the Criminal Code of Ukraine. In the course of the analysis of scientific works concerning the issue of the definition of the subject of a crime "state treason", it is established that in the theory of domestic criminal law this issue was studied indirectly, which leads to an objective need for its detailed study. The article reveals the content of the features of the subject of crime, provided for in Art. 111 of the Criminal Code of Ukraine, by analyzing its mandatory features - the physical nature, conviction and age from which criminal liability may arise, as well as a special feature - the citizenship of Ukraine. The arguments in support of reducing the age of a person for whom he or she may be held criminally responsible for treason are analyzed. At the same time, the situation in which minors of Ukraine who live on the territory of quasi-state entities of the DNR, LNR and the annexed part of Ukraine - the AR of Crimea has been investigated. It is established that in such circumstances, through psycho-physiological and social peculiarities of the development of these persons, through anti-Ukrainian influence is exercised, which does not exclude the possibility of conscious actions to the detriment of the state sovereignty of Ukraine by persons under 16 years of age. Investigating the special feature of criminal "state treason", it is established that the norms of the current legislation of Ukraine governing the issue of loss of Ukrainian citizenship are debatable and today poses a real threat to national security. In particular, it was found that the voluntary acquisition of the citizenship of another state by a citizen of Ukraine, if at the time of such acquisition he reached the age of majority is one of the reasons for the loss of the citizenship of Ukraine, however, the mechanism of implementation of this prescription is not provided by the Law, which creates a number of contradictions. In the course of the study of the Bill № 2590 "On Amendments to Certain Lawes of Ukraine on Citizenship", which was submitted to the Verkhovna Rada of Ukraine in December 2019, it was found that some of its provisions are intended to address the gaps in the legislative framework on citizenship of Ukraine.

Key words: subject of the crime, individual, guilty person, age of criminal responsibility, lowering the limit, special subject of crime, citizenship of Ukraine. 